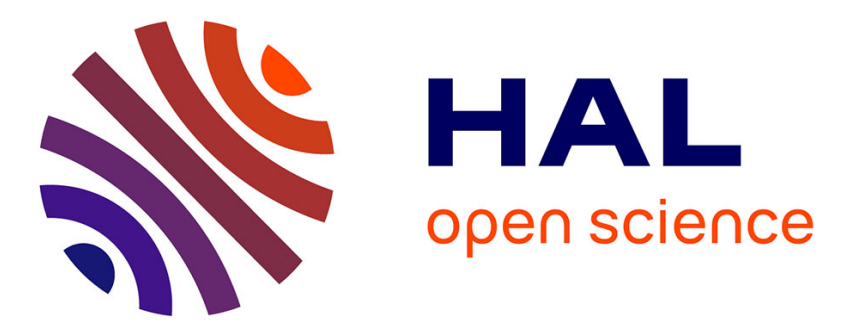

\title{
In vitro evaluation of sugar syrups, antibiotics, and miticides on growth of honey bee pathogen, Ascosphaera apis: Emphasis for chalkbrood prevention is on keeping bees healthy
}

Jay Yoder, Andrew Jajack, William Cornacchione, Allison Dunn, Edward

Cunningham, Caroline Matchett, Andrew Rosselot

\section{To cite this version:}

Jay Yoder, Andrew Jajack, William Cornacchione, Allison Dunn, Edward Cunningham, et al.. In vitro evaluation of sugar syrups, antibiotics, and miticides on growth of honey bee pathogen, Ascosphaera apis: Emphasis for chalkbrood prevention is on keeping bees healthy. Apidologie, 2014, 45 (5), pp.568578. 10.1007/s13592-014-0274-5 . hal-01234755

\section{HAL Id: hal-01234755 \\ https://hal.science/hal-01234755}

Submitted on 27 Nov 2015

HAL is a multi-disciplinary open access archive for the deposit and dissemination of scientific research documents, whether they are published or not. The documents may come from teaching and research institutions in France or abroad, or from public or private research centers.
L'archive ouverte pluridisciplinaire HAL, est destinée au dépôt et à la diffusion de documents scientifiques de niveau recherche, publiés ou non, émanant des établissements d'enseignement et de recherche français ou étrangers, des laboratoires publics ou privés. 


\title{
In vitro evaluation of sugar syrups, antibiotics, and miticides on growth of honey bee pathogen, Ascosphaera apis: Emphasis for chalkbrood prevention is on keeping bees healthy
}

\author{
Jay A. Yoder, Andrew J. Jajack, William S. Cornacchione, Allison L. Dunn, \\ Edward G. Cunningham, Caroline L. Matchett, Andrew E. Rosselot
}

Department of Biology, Wittenberg University, Springfield, OH 45501, USA

Received 13 September 2013 - Revised 1 December 2013 - Accepted 21 January 2014

\begin{abstract}
To examine the link between chalkbrood and treatments applied to honey bee (Apis mellifera) colonies, growth of Ascosphaera apis was determined under chalkbrood-inducing conditions on agar containing crushed bee larvae as a mock infection. Treatments were tested at concentrations in the field, representative of beekeeping practice (at least in the USA). A chilling or warming stress known to heighten chalkbrood caused no growth enhancement of $A$. apis. Miticides had a negative effect; formic acid killed $A$. apis and oxalic acid reduced growth by $70 \%$. High-fructose corn syrups and sucrose syrup undiluted, a 50:50 mixture, alone, and with antibiotics did not alter growth of $A$. apis. We conclude that chalkbrood does not develop from a temperature- or treatment-induced activation of $A$. apis. Sugar syrups, miticides, and antibiotics point out other health problems that make bees prone to infection by A. apis. Thus, chalkbrood opportunistically infects bees under other forms of stress.
\end{abstract}

bee colony / mycosis / formic acid / oxalic acid / high-fructose corn syrup / antibiotics

\section{INTRODUCTION}

Chalkbrood, a lethal mummification disease of bee larvae caused by the common honey bee colony fungal resident, Ascosphaera apis, is promoted either by a chilling shock $\left(18{ }^{\circ} \mathrm{C}\right.$; Flores et al. 1996) or warming shock $\left(36{ }^{\circ} \mathrm{C}\right.$; Gilliam 1986; Gilliam et al. 1988) to the bee brood. Only a $24 \mathrm{~h}$ exposure at these temperature extremes is sufficient to incite a high incidence of chalkbrood (Flores et al. 1996). Correspondingly, edges of frames in the colony that are more subjected to outdoor temperature

Corresponding author: J. Yoder, jyoder@wittenberg.edu

Manuscript editor: Peter Rosenkranz fluctuations are where the majority of chalkbrood mummies are found, leaving brood uninfected that are at the interior to the bee colony where the temperature is held relatively stable $32{ }^{\circ} \mathrm{C}-35{ }^{\circ} \mathrm{C}$ from bee activity (Cooper 1980; Southwick and Heldmaier 1987; Flores et al. 1996). The chalkbrood mummy is the killed remains of an infected bee larva, a hardened, whitish gray, dried fungal mycelium from $A$. apis that took over the bee larva from the inside out, originating from conidia (spores) in bee bread that were fed by adults to the developing larvae (Aronstein and Cabanillas 2012). Chalkbrood is spread throughout a colony and transmitted to new colonies by re-use of old chalkbrood-contaminated frames and hive construction materials due to the sporing activity that accompanies fungal growth. Hygienic bees 
have a way of recovering from chalkbrood by chewing out the infected cells and re-building the damaged areas (D. Sammataro, USDAARS, Tucson, Arizona; personal communication 2013). This cleaning behavior opens up the cells liberating large amounts of conidia that circulate around the colony allowing the infection to persist. Chalkbrood is rarely seen in treatment-free colonies, and the lack of sugar feeding also seems to contribute to an absence of chalkbrood in these colonies (L. R. Herboltzheimer and D. Stiglitz, Golden Rule Honey, Leominster, Massachusetts; personal communication 2013). In contrast, symptoms of chalkbrood appear in bee colonies that can be traced as having a history of regular treatments of antibiotics, miticides, and sugar syrups based on the reports of many commercial beekeepers (J. Finley; personal communication 2013). Indeed, it was their observations that prompted our own investigation.

Not all beekeepers do the same thing when treating their colonies. In the USA, bees are routinely treated by most beekeepers, whether the bees are already compromised or not (D. Stiglitz, Golden Rule Honey, Leominster, Massachusetts; personal communication 2013). Generally, high-fructose corn syrups (HFCS) are fed to the colony either undiluted or as a 50:50 mixture with sucrose syrup and usually not diluted with water (E. Mussen, University of California, Davis, California; personal communication 2013). Sugar syrups are used to promote brood rearing in the spring-during the winter months or when honey-producing plants are scarce. Some antibiotics, such as fumagillin, are mixed in syrup and fed to bees; other antibiotics are also administered in confectioner sugar as a dusting over the frames. For the common antibiotics that are used, concentrations are $0.1 \%$ fumagillin for nosemosis control (microsporidian Nosema apis Katznelson and Jamieson 1952 but not $N$. ceranae Huang et al. 2013), $1 \%$ tylosin, or $1 \%$ oxytetracycline are used for controlling American or European foulbrood (bacterium Paenibacillus larvae Hitchcock et al. 1970; Peng et al. 1996), basing the calculation on
20 g sugar/colony according to package directions supplied by the manufacturers. Some miticides in the organic acid class for controlling varroa mite infestations are formic acid and oxalic acid (Sammataro 2012); there are also thymol-based and synthetic miticides. Pads or fumigators using concentrations at $50 \%$ formic acid/liter are typical ways that formic acid is applied to the colony (Amrine et al. 2007), although concentrations can range between 25$65 \%$ formic acid/liter depending on desired level of treatment (Underwood and Currie 2005). Formic acid can be antifungal against A. apis (Sahinler and Kurt 2004). Some beekeepers use oxalic acid, following the advice of Randy Oliver (Grass Valley, California) using an oxalic drip made from water and a small amount of sugar to make a syrup consisting of $3.5 \%$ oxalic acid (Aliano et al. 2006; Rademacher and Harz 2006) and then adapted their own methods from this (E. Mussen, University of California, Davis, California; personal communication 2013). Oxalic acid is a well-known, common antifungal (Yamaji et al. 2005), and it can slow the growth of $A$. apis (Yoder et al. 2008), but it is not known how $A$. apis behaves in response to field concentrations.

The goal of this study was to examine temperature effects, implementing chilling and warming shocks, on growth of A. apis in culture, determining whether these strong chalkbrood-inducing conditions are synergized with antibiotics, miticides, and sugar syrups. We made our experiments applicable to what occurs in a field setting by testing the various treatments at concentrations and delivery methods that active beekeepers use (at least in the USA). So that growth of the fungus would reflect how the fungus would behave inside an actual bee larva as its sole source of nutrition, we conducted experiments on supplemented agar growth media containing crushed bee larvae. The intent was to clarify growth characteristics of $A$. apis by making the experiments more relevant to the bee colony, chalkbrood associations, and field concentration of treatments. Our hypothesis was that growth of $A$. apis may be enhanced by antibiotics, miticides, and sugar 
syrups matching the high frequency of chalkbrood symptoms in treated bee colonies observed in the field.

\section{MATERIALS AND METHODS}

\subsection{Syrups, antibiotics, and miticides}

Isosweet $^{(\mathbb{2}} 100$ (Tate and Lyle, Decatur, Illinois); Cornsweet $^{\circledR} 42$ (Archer Daniels Midland, Decatur, Illinois); Hi-Sweet 55 (Roquette America, Keokuk, Iowa); and Mann Lake High Fructose Corn Syrup ${ }^{\circledR}$ 55 (Mann Lake, Hackensack, Minnesota) were the high-fructose corn syrups that were tested. The sucrose syrup was Mann Lake Sucrose Syrup ${ }^{\circledR}$ (Mann Lake, Hackensack, Minnesota). Antibiotics that were tested included fumagillin (Fumagilin- ${ }^{\mathbb{B}}$, fumagillin dicyclohexylammonium; Medivet Pharmaceuticals Ltd., High River, AB, Canada), tylosin (Tylan ${ }^{\mathbb{B}}$, tylosin tartrate; Eli Lilly Co., Indianapolis, Indiana), and oxytetracycline (Terramycin ${ }^{\circledR}$, oxytetracycline hydrochloride; Pfizer Inc., New York, New York). Formic acid and oxalic acid ( $\geq 99 \%$ pure; Sigma; St. Louis, Missouri) were the miticides that were tested. All were taken directly from the packaging supplied by the manufacturer. Dilutions were made using double distilled deionized (DI) water, and all solution preparation was done in glass. The negative control was DI water. The positive control was the fungicide Amphotericin B $(100 \mu \mathrm{g} / \mathrm{mL}$; Sigma Chemical Co., St. Louis, Missouri) (Jimenez et al. 1994). How these treatments (referred to as a "test compound") were administered in the experiment are in section 2.4., "Determination of fungal growth rate" below.

\subsection{Fungi}

A. apis was obtained by embedding a chalkbrood mummy (source: Carl Hayden Bee Research Center, Tucson, Arizona) into potato dextrose agar (PDA) + $0.4 \%$ yeast extract in $100 \times 15 \mathrm{~mm}$ sterile, disposable Petri plates (Fisher Scientific, Pittsburgh, Pennsylvania). Plates were incubated at $25 \pm 0.5{ }^{\circ} \mathrm{C}$ and darkness (Johnson et al. 2005). Twenty mummies were used from five different colonies so that $A$. apis came from more than one source, instead of from a single mummy. Tips from hyphae that could be traced as having originated from the mummy surface by light microscopy were cut from the agar as a $1 \mathrm{~cm}^{3}$ block, placed on a fresh PDA plate, and grown until colony characteristics (conidia and phialide) appeared. Identification was determined by examination under oil $(1,000 \times$, light microscopy) using criteria of Christensen and Gilliam (1983) and by comparison to pure A. apis isolates (Carl Hayden Bee Research Center, Tucson, Arizona) as there can be multiple kinds of fungi, other than A. apis, found in chalkbrood mummies (Johnson et al. 2005). We did three rounds of subculturing of A. apis to establish purity.

\subsection{Incubation temperatures}

All temperatures were controlled using programmable incubators $\left(< \pm 0.5{ }^{\circ} \mathrm{C}\right.$; Fisher Scientific, Pittsburgh, Pennsylvania). Relative humidity within the incubator was $75 \% \pm 2.0 \% \mathrm{RH}$ (measured with a hygrometer, $\mathrm{SD} \pm 0.5 \% \mathrm{RH}$; Thomas Scientific, Philadelphia, Pennsylvania), adjusted with saturated $\mathrm{NaCl}$ solution that maintains the relative humidity over a broad temperature range (Winston and Bates 1960). The $75 \% \mathrm{RH}$ is approximately midpoint between $60-80 \% \mathrm{RH}$ of colony conditions (Chiesa et al. 1989). Incubation temperatures were as follows:

$18{ }^{\circ} \mathrm{C}=$ chilling stress for $24 \mathrm{~h}$ that triggers a high incidence of chalkbrood in the colony (Flores et al. 1996), also corresponds to the lowest temperature measurement of the colony around the edges of frames that are closest to the outer environment (Cooper 1980);

$25{ }^{\circ} \mathrm{C}=$ temperature that yields highest percentage of chalkbrood mummies in the colony, corresponding to onset of chalkbrood infection (Flores et al. 1996);

$30{ }^{\circ} \mathrm{C}=$ "critical temperature" for measuring chalkbrood in the colony (Flores et al. 1996); $32{ }^{\circ} \mathrm{C}=$ average temperature of brood area and colony environment that is required for brood development (Cooper 1980);

$35{ }^{\circ} \mathrm{C}=$ temperature of the central brood area (Southwick and Heldmaier 1987), and this is also the temperature where incidence of chalkbrood drops severely corresponding to the onset of infection (Flores et al. 1996); and 
$36{ }^{\circ} \mathrm{C}=$ warming stress for $24 \mathrm{~h}$ that triggers a high incidence of chalkbrood in the colony (Gilliam 1986; Gilliam et al. 1988) and also represents the highest temperature measurement of the colony at the edges of the frames closest to the outer environment (Cooper 1980).

To perform the warm-shock treatment in the experiment, the Petri plate containing A. apis (set up at per section 2.4 below) was first placed at $36{ }^{\circ} \mathrm{C}$ for $24 \mathrm{~h}$ and then it was transferred to $25^{\circ} \mathrm{C}$. Another group of Petri plates was transferred from $36{ }^{\circ} \mathrm{C}$ after $24 \mathrm{~h}$ to $30{ }^{\circ} \mathrm{C}$. Another group of Petri plates was transferred from $36{ }^{\circ} \mathrm{C}$ after $24 \mathrm{~h}$ to $32{ }^{\circ} \mathrm{C}$. Another group of Petri plates was transferred from $36{ }^{\circ} \mathrm{C}$ after $24 \mathrm{~h}$ to $35{ }^{\circ} \mathrm{C}$. To perform the chill-shock treatment, the same protocol was followed except the first $24 \mathrm{~h}$ exposure was at $18{ }^{\circ} \mathrm{C}$, rather than at $36{ }^{\circ} \mathrm{C}$, before transferring the plates to $25^{\circ} \mathrm{C}, 30^{\circ} \mathrm{C}, 32{ }^{\circ} \mathrm{C}$, and $35{ }^{\circ} \mathrm{C}$.

\subsection{Determination of fungal growth rate}

Agar growth media (Fisher) were PDA (mycological standard); lactic acid-acidified PDA, pH 5.5 (APDA); modified Melin-Norkrans agar (MMN); and bee larva-infused non-nutritive agar (BLA), made from crushed, autoclave-sterilized $\left(121{ }^{\circ} \mathrm{C}, 15 \mathrm{psi}\right)$ whole larvae added into the agar at one $9.04 \mathrm{mg}$ larva equivalent/plate, using solidified agar in $100 \times 15 \mathrm{~mm}$ Petri plates (Fisher). Two lines were drawn across the middle of the plate, dividing the plate into quadrants. A $1.5 \mathrm{~cm}$ well was punched out of the agar at the middle of plate over top where the two lines intersected. A $1 \mathrm{~cm}^{3}$ block of A. apis (white periphery of pure, established culture) was placed into the well. Then the well was filled with $200 \mu \mathrm{L}$ of test compound with a micropipette $( \pm \mathrm{SE}<0.03 \%$; Fisher). Plates were incubated in darkness at the test temperatures specified above. Plates were removed daily, examined by light microscopy, and a series of five consecutive measurements were taken $(40 \times)$ along each of the four lines as the mycelium spread over the agar surface. The measurements were fit to the following equation: $K_{\mathrm{r}}=\left(\mathrm{R}_{1}-\mathrm{R}_{0}\right) /\left(\mathrm{t}_{1}-\mathrm{t}_{0}\right)$, where $K_{\mathrm{r}}$ is the radial growth rate, $R_{0}$ and $R_{1}$ are colony radii at beginning of linear, and $t_{0}$ and stationary, $t_{1}$, phases of growth (Baldrian and Gabriel 2002). Blocks of $A$. apis that failed to show emergence of hyphae by $450 \times$ microscopy were defined as no growth; i.e., $K_{\mathrm{r}}=0.00 \mathrm{~mm} / \mathrm{h}$.

\subsection{Sample sizes and statistics}

Each experiment was replicated five times, using a different mummy as the source of $A$. apis for each replicate. A radial growth rate $\left(K_{\mathrm{r}}\right)$ was calculated for each line; thus, there were four $K_{\mathrm{r}}$ determinations/ plate (total $n=20$, based on total of 100 individual measurements). Each radial growth rate is the mean \pm SE. Radial growth rates were compared with an analysis of variance (Duncan; ANOVA; $P=0.05$; SPSS 14.0 for Windows, Microsoft Excel and Minitab; Chicago, Illinois; Sokal and Rohlf 1995).

\section{RESULTS}

\subsection{Temperature effects}

Growth rate of $A$. apis increased with increasing temperature, yielding a significant difference when growth rates were compared between a lower temperature with a higher temperature (Figure 1; $P<0.05$ ). No significant differences between growth rates at a particular temperature were noted as the result of chillshocked and not chill-shocked A. apis (Figure 1; $P>0.05)$. Growth rate of warm-shocked and untreated $A$. apis were not significantly different at each temperature (Figure $1 ; P>0.05$ ). In all cases, there was no growth $\left(K_{\mathrm{r}}=0.00 \mathrm{~mm} / \mathrm{h}\right)$ at each temperature for $A$. apis that had been treated with amphotericin, and this was significantly different from the measurable growth rates in the treatments with water (Figure 1; $P<$ 0.05). Bee larva agar, BLA (Figure 1, Tables I, II, III, and IV) yielded nearly identical growth rates as other agar growth media, PDA, APDA $\mathrm{pH} 5.5$, and MMN (data not shown).

\subsection{Syrup effects}

There was no significant difference between growth rates of $A$. apis having been treated with high-fructose corn syrup (Table I) and the water controls when each temperature group was 


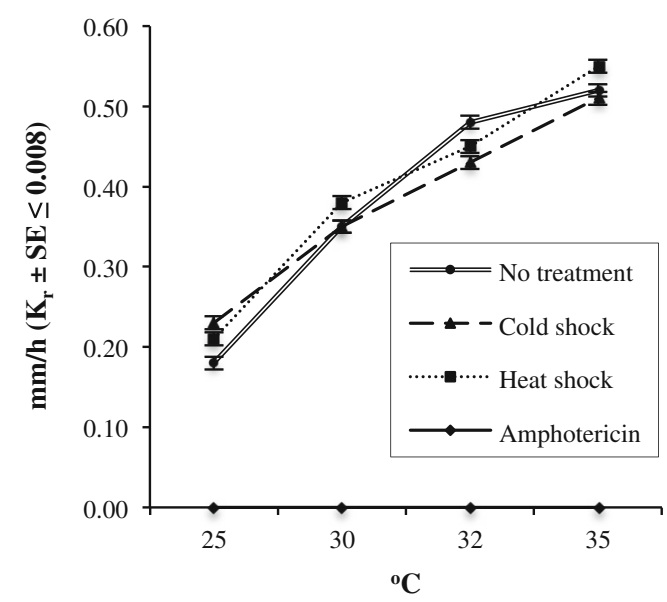

Figure 1. Temperature-growth profile on nonnutritive agar containing crushed bees, comparing no pre-treatment, chill shock pre-treatment $(24 \mathrm{~h}$ at $\left.18{ }^{\circ} \mathrm{C}\right)$, and warm shock pre-treatment $\left(24 \mathrm{~h}\right.$ at $\left.36^{\circ} \mathrm{C}\right)$ showing increase in the radial growth rate, $\mathrm{mm} / \mathrm{h}\left(K_{\mathrm{r}}\right.$ $\pm \mathrm{SE} \leq 0.008)$ of Ascosphaera apis. These data are for the water-treated controls. Amphotericin treatment, $K_{\mathrm{r}}=0.00 \mathrm{~mm} / \mathrm{h}$ compared (Figure 1; $P>0.05$ ). Chill shocking and warm shocking also had no significant effect on growth rates of $A$. apis compared to water-treated controls at each of the test temperatures (Figure 1, Table I; $P>0.05$ ). An exception was seen when comparing across treatments (Table I). When looking across rows in Table I, A. apis treated with Cornsweet grew at a significantly slower rate (averaging $1.5 \times$ slower) than the other brands, Hi-Sweet $(P>$ 0.05 at each temperature setting), Isosweet $(P>$ 0.05 at each temperature setting), Mann Lake $(P>0.05$ at each temperature setting) (Table I), and the water-treated control (Figure 1; $P>0.05$ at each temperature setting). A. apis that had been treated with sucrose syrup responded similarly as it did toward high-fructose corn syrups, Hi-sweet, Isosweet, Mann Lake, and water-treated controls, showing similar growth rates at each temperature (Table I, Figure 1; $P>$ $0.05)$, except for Cornsweet that was slightly lower $(P<0.05$; Table I).

Table I. Different brands of sugar syrup (tested undiluted, as applied in the field) and their lack of effect, except for lowering by Cornsweet $(P<0.05)$, on the growth rate of Ascosphaera apis on bee larva-supplemented media

Mean radial growth rate, $\mathrm{mm} / \mathrm{h}\left(K_{\mathrm{r}} \pm \mathrm{SE} \leq 0.007\right)$

\begin{tabular}{llllll}
\hline Temperature & $\begin{array}{l}\text { HFCS } \\
\text { Cornsweet }\end{array}$ & $\begin{array}{l}\text { HFCS } \\
\text { Hi-sweet }\end{array}$ & $\begin{array}{l}\text { HFCS } \\
\text { Isosweet }\end{array}$ & $\begin{array}{l}\text { HFCS } \\
\text { Mann Lake }\end{array}$ & $\begin{array}{l}\text { SS } \\
\text { Mann Lake }\end{array}$ \\
\hline $25^{\circ} \mathrm{C}$ & $0.15^{\mathrm{a}}$ & $0.23^{\mathrm{a}}$ & $0.25^{\mathrm{a}}$ & $0.18^{\mathrm{a}}$ & $0.21^{\mathrm{a}}$ \\
Chill shock & $0.12^{\mathrm{a}}$ & $0.19^{\mathrm{a}}$ & $0.21^{\mathrm{a}}$ & $0.24^{\mathrm{a}}$ & $0.21^{\mathrm{a}}$ \\
Warm shock & $0.10^{\mathrm{a}}$ & $0.24^{\mathrm{a}}$ & $0.20^{\mathrm{a}}$ & $0.19^{\mathrm{a}}$ & $0.24^{\mathrm{a}}$ \\
$30^{\circ} \mathrm{C}$ & $0.24^{\mathrm{b}}$ & $0.33^{\mathrm{b}}$ & $0.34^{\mathrm{b}}$ & $0.27^{\mathrm{b}}$ & $0.36^{\mathrm{b}}$ \\
Chill shock & $0.25^{\mathrm{b}}$ & $0.30^{\mathrm{b}}$ & $0.35^{\mathrm{b}}$ & $0.28^{\mathrm{b}}$ & $0.34^{\mathrm{b}}$ \\
Warm shock & $0.21^{\mathrm{b}}$ & $0.29^{\mathrm{b}}$ & $0.30^{\mathrm{b}}$ & $0.28^{\mathrm{b}}$ & $0.28^{\mathrm{b}}$ \\
$32{ }^{\circ} \mathrm{C}$ & $0.29^{\mathrm{c}}$ & $0.40^{\mathrm{c}}$ & $0.41^{\mathrm{c}}$ & $0.45^{\mathrm{c}}$ & $0.42^{\mathrm{c}}$ \\
Chill shock & $0.27^{\mathrm{c}}$ & $0.39^{\mathrm{c}}$ & $0.41^{\mathrm{c}}$ & $0.44^{\mathrm{c}}$ & $0.40^{\mathrm{c}}$ \\
Warm shock & $0.30^{\mathrm{c}}$ & $0.42^{\mathrm{c}}$ & $0.43^{\mathrm{c}}$ & $0.39^{\mathrm{c}}$ & $0.45^{\mathrm{c}}$ \\
$35^{\circ} \mathrm{C}$ & $0.40^{\mathrm{d}}$ & $0.49^{\mathrm{d}}$ & $0.53^{\mathrm{d}}$ & $0.56^{\mathrm{d}}$ & $0.52^{\mathrm{d}}$ \\
Chill shock & $0.39^{\mathrm{d}}$ & $0.52^{\mathrm{d}}$ & $0.51^{\mathrm{d}}$ & $0.50^{\mathrm{d}}$ & $0.49^{\mathrm{d}}$ \\
Warm shock & $0.39^{\mathrm{d}}$ & $0.55^{\mathrm{d}}$ & $0.48^{\mathrm{d}}$ & $0.53^{\mathrm{d}}$ & $0.53^{\mathrm{d}}$ \\
\hline
\end{tabular}

Chill shock, pre-exposure at $18{ }^{\circ} \mathrm{C}$ for $24 \mathrm{~h}$; warm shock, pre-exposure at $36{ }^{\circ} \mathrm{C}$ for $24 \mathrm{~h}$. Data followed by the same superscript letter going down a column of values are not significantly different. Data for water-treated controls are in Figure 1, and statistical comparisons are made in 3.2. in the "Results" section

HFCS high-fructose corn syrup, SS sucrose syrup 
Table II. Effect of antibiotics (* denotes suggested field application concentration) that has no effect the growth rate of Ascosphaera apis. Incubation pre-treatment: $18{ }^{\circ} \mathrm{C}$ for $24 \mathrm{~h}$ (chill shock) and $36{ }^{\circ} \mathrm{C}$ for $24 \mathrm{~h}$ (warm shock). Bee larva-supplemented agar was the growth medium

Mean radial growth rate, $\mathrm{mm} / \mathrm{h}\left(K_{\mathrm{r}} \pm \mathrm{SE} \leq 0.009\right)$

\begin{tabular}{|c|c|c|c|c|c|c|c|c|c|}
\hline \multirow[b]{2}{*}{ Temperature } & \multicolumn{3}{|c|}{$\%$ Fumagillin } & \multicolumn{3}{|c|}{$\%$ Oxytetracycline } & \multicolumn{3}{|c|}{$\%$ Tylosin } \\
\hline & 0.01 & $0.1^{*}$ & 1.0 & 0.01 & 0.1 & $1.0^{*}$ & 0.01 & 0.1 & $1.0^{*}$ \\
\hline $25^{\circ} \mathrm{C}$ & $0.25^{\mathrm{a}}$ & $0.23^{\mathrm{a}}$ & $0.24^{\mathrm{a}}$ & $0.18^{\mathrm{a}}$ & $0.24^{\mathrm{a}}$ & $0.20^{\mathrm{a}}$ & $0.25^{\mathrm{a}}$ & $0.17^{\mathrm{a}}$ & $0.24^{\mathrm{a}}$ \\
\hline Chill shock & $0.19^{\mathrm{a}}$ & $0.19^{\mathrm{a}}$ & $0.25^{\mathrm{a}}$ & $0.24^{\mathrm{a}}$ & $0.22^{\mathrm{a}}$ & $0.20^{\mathrm{a}}$ & $0.19^{\mathrm{a}}$ & $0.18^{\mathrm{a}}$ & $0.23^{\mathrm{a}}$ \\
\hline Warm shock & $0.23^{\mathrm{a}}$ & $0.24^{\mathrm{a}}$ & $0.23^{\mathrm{a}}$ & $0.21^{\mathrm{a}}$ & $0.20^{\mathrm{a}}$ & $0.19^{\mathrm{a}}$ & $0.23^{\mathrm{a}}$ & $0.23^{\mathrm{a}}$ & $0.24^{\mathrm{a}}$ \\
\hline $30^{\circ} \mathrm{C}$ & $0.29^{\mathrm{b}}$ & $0.35^{\mathrm{b}}$ & $0.30^{\mathrm{b}}$ & $0.28^{\mathrm{b}}$ & $0.34^{\mathrm{b}}$ & $0.33^{\mathrm{b}}$ & $0.28^{\mathrm{b}}$ & $0.32^{\mathrm{b}}$ & $0.33^{b}$ \\
\hline Chill shock & $0.34^{\mathrm{b}}$ & $0.29^{\mathrm{b}}$ & $0.28^{\mathrm{b}}$ & $0.34^{\mathrm{b}}$ & $0.30^{\mathrm{b}}$ & $0.29^{\mathrm{b}}$ & $0.35^{\mathrm{b}}$ & $0.28^{\mathrm{b}}$ & $0.28^{\mathrm{b}}$ \\
\hline Warm shock & $0.28^{\mathrm{b}}$ & $0.30^{\mathrm{b}}$ & $0.33^{\mathrm{b}}$ & $0.28^{\mathrm{b}}$ & $0.32^{\mathrm{b}}$ & $0.29^{\mathrm{b}}$ & $0.31^{\mathrm{b}}$ & $0.29^{\mathrm{b}}$ & $0.34^{\mathrm{b}}$ \\
\hline $32{ }^{\circ} \mathrm{C}$ & $0.40^{\mathrm{c}}$ & $0.38^{\mathrm{c}}$ & $0.42^{\mathrm{c}}$ & $0.42^{\mathrm{c}}$ & $0.39^{\mathrm{c}}$ & $0.40^{\mathrm{c}}$ & $0.44^{\mathrm{c}}$ & $0.44^{\mathrm{c}}$ & $0.39^{\mathrm{c}}$ \\
\hline Chill shock & $0.42^{\mathrm{c}}$ & $0.40^{\mathrm{c}}$ & $0.45^{\mathrm{c}}$ & $0.40^{\mathrm{c}}$ & $0.43^{\mathrm{c}}$ & $0.38^{\mathrm{c}}$ & $0.44^{\mathrm{c}}$ & $0.37^{\mathrm{c}}$ & $0.40^{\mathrm{c}}$ \\
\hline Warm shock & $0.42^{\mathrm{c}}$ & $0.38^{\mathrm{c}}$ & $0.43^{\mathrm{c}}$ & $0.37^{\mathrm{c}}$ & $0.41^{\mathrm{c}}$ & $0.40^{\mathrm{c}}$ & $0.39^{\mathrm{c}}$ & $0.41^{\mathrm{c}}$ & $0.43^{\mathrm{c}}$ \\
\hline $35^{\circ} \mathrm{C}$ & $0.52^{\mathrm{d}}$ & $0.48^{\mathrm{d}}$ & $0.49^{\mathrm{d}}$ & $0.52^{\mathrm{d}}$ & $0.48^{\mathrm{d}}$ & $0.50^{\mathrm{d}}$ & $0.53^{\mathrm{d}}$ & $0.56^{\mathrm{d}}$ & $0.51^{\mathrm{d}}$ \\
\hline Chill shock & $0.57^{\mathrm{d}}$ & $0.54^{\mathrm{d}}$ & $0.53^{\mathrm{d}}$ & $0.54^{\mathrm{d}}$ & $0.52^{\mathrm{d}}$ & $0.47^{\mathrm{d}}$ & $0.48^{\mathrm{d}}$ & $0.54^{\mathrm{d}}$ & $0.49^{\mathrm{d}}$ \\
\hline Warm shock & $0.49^{\mathrm{d}}$ & $0.53^{\mathrm{d}}$ & $0.51^{\mathrm{d}}$ & $0.49^{\mathrm{d}}$ & $0.53^{\mathrm{d}}$ & $0.52^{\mathrm{d}}$ & $0.49^{\mathrm{d}}$ & $0.54^{\mathrm{d}}$ & $0.54^{\mathrm{d}}$ \\
\hline
\end{tabular}

A different superscript letter going down a column of data means there is a significant difference. The "Results" section 3.3 provides statistical information for comparing these values to water-treated controls in Figure 1

\subsection{Antibiotic effects}

Treatment with fumagillin did not alter the growth rate of $A$. apis, and at each temperature setting, the growth rate of $A$. apis (Table II) compared favorably to the growth rate of watertreated controls (Figure 1; $P>0.05$ for each temperature setting). This included when chill and warm shocks were applied: growth rates were not significantly different compared to control growth rates (Table II, Figure 1; $P>$ $0.05)$. Additionally, there was no dose response; i.e., even at the highest concentration of $1 \%$ fumagillin tested, the growth rate of $A$. apis responded like a water-treated control $(P>$ 0.05 at each test temperature). Similar trends of no dose response, no effect of chill and warm shock cues, and unmodified growth rates of $A$. apis were observed for treatments with oxytetracycline (Table II compared to Figure 1; $P>0.05$ ) and tylosin (Table II vs. Figure $1 ; P>0.05)$.
Adding high-fructose corn syrup to fumagillin, oxytetracycline, and tylosin (only field concentrations were tested; Table III) did not modify the growth of $A$. apis compared to water-treated controls as shown in Figure $1(P>$ $0.05)$. There was also no significant effect at each temperature setting, including implementing a chill or warm shock cue, forhigh fructose corn syrup cut 50:50 with sucrose syrup on growth rate of $A$. apis with $(P>0.05$; Table III) or without antibiotic $(P>0.05$, in each comparison between antibiotic treatments to water-treated controls; Table III, Figure 1). Increasing temperature caused an increase in growth rate $(P<0.05)$, with lowest growth at the lowest temperature, and highest growth at the highest temperature setting (Tables II and III). Implementing chill and warm shock cues had no effect on modifying the growth rate of $A$. apis compared to growth rates when these cues were not applied $(P>0.05$; Tables II and III). 
Table III. Comparison of antibiotic delivery methods (all are ways these are applied in the field, syrups undiluted, or cut 50:50 with sucrose syrup) showing no effect on growth rate of Ascosphaera apis combined with a chilling $\left(18{ }^{\circ} \mathrm{C}, 24 \mathrm{~h}\right)$ or warming $\left(36^{\circ} \mathrm{C}, 24 \mathrm{~h}\right)$ pre-treatment shock

Mean radial growth rate, $\mathrm{mm} / \mathrm{h}\left(K_{\mathrm{r}} \pm \mathrm{SE} \leq 0.004\right)$

\begin{tabular}{|c|c|c|c|c|c|c|c|}
\hline \multirow[b]{2}{*}{ Temperature } & \multirow[b]{2}{*}{$\mathrm{HFCS}+\mathrm{SS}$} & \multicolumn{2}{|c|}{$0.1 \%$ Fumagillin } & \multicolumn{2}{|c|}{$1.0 \%$ Oxytetracycline } & \multicolumn{2}{|c|}{$1.0 \%$ Tylosin } \\
\hline & & HFCS & $\mathrm{HFCS}+\mathrm{SS}$ & HFCS & $\mathrm{HFCS}+\mathrm{SS}$ & HFCS & $\mathrm{HFCS}+\mathrm{SS}$ \\
\hline $25^{\circ} \mathrm{C}$ & $0.19^{\mathrm{a}}$ & $0.18^{\mathrm{a}}$ & $0.21^{\mathrm{a}}$ & $0.20^{\mathrm{a}}$ & $0.22^{\mathrm{a}}$ & $0.22^{\mathrm{a}}$ & $0.23^{\mathrm{a}}$ \\
\hline Chill shock & $0.18^{\mathrm{a}}$ & $0.23^{\mathrm{a}}$ & $0.22^{\mathrm{a}}$ & $0.23^{\mathrm{a}}$ & $0.20^{\mathrm{a}}$ & $0.19^{\mathrm{a}}$ & $0.23^{\mathrm{a}}$ \\
\hline Warm shock & $0.23^{\mathrm{a}}$ & $0.23^{\mathrm{a}}$ & $0.19^{\mathrm{a}}$ & $0.18^{\mathrm{a}}$ & $0.23^{\mathrm{a}}$ & $0.21^{\mathrm{a}}$ & $0.19^{\mathrm{a}}$ \\
\hline $30^{\circ} \mathrm{C}$ & $0.33^{\mathrm{b}}$ & $0.28^{\mathrm{b}}$ & $0.28^{\mathrm{b}}$ & $0.27^{\mathrm{b}}$ & $0.35^{\mathrm{b}}$ & $0.28^{\mathrm{b}}$ & $0.30^{\mathrm{b}}$ \\
\hline Chill shock & $0.37^{\mathrm{b}}$ & $0.31^{\mathrm{b}}$ & $0.29^{\mathrm{b}}$ & $0.34^{\mathrm{b}}$ & $0.28^{\mathrm{b}}$ & $0.30^{\mathrm{b}}$ & $0.29^{\mathrm{b}}$ \\
\hline Warm shock & $0.29^{\mathrm{b}}$ & $0.34^{\mathrm{b}}$ & $0.28^{\mathrm{b}}$ & $0.28^{\mathrm{b}}$ & $0.32^{\mathrm{b}}$ & $0.31^{\mathrm{b}}$ & $0.34^{\mathrm{b}}$ \\
\hline $32{ }^{\circ} \mathrm{C}$ & $0.41^{\mathrm{c}}$ & $0.39^{\mathrm{c}}$ & $0.39^{\mathrm{c}}$ & $0.42^{\mathrm{c}}$ & $0.43^{\mathrm{c}}$ & $0.39^{\mathrm{c}}$ & $0.40^{\mathrm{c}}$ \\
\hline Chill shock & $0.44^{\mathrm{c}}$ & $0.41^{\mathrm{c}}$ & $0.41^{\mathrm{c}}$ & $0.40^{\mathrm{c}}$ & $0.42^{\mathrm{c}}$ & $0.45^{\mathrm{c}}$ & $0.39^{\mathrm{c}}$ \\
\hline Warm shock & $0.38^{\mathrm{c}}$ & $0.40^{\mathrm{c}}$ & $0.39^{\mathrm{c}}$ & $0.32^{\mathrm{c}}$ & $0.44^{\mathrm{c}}$ & $0.41^{\mathrm{c}}$ & $0.40^{\mathrm{c}}$ \\
\hline $35^{\circ} \mathrm{C}$ & $0.49^{\mathrm{d}}$ & $0.50^{\mathrm{d}}$ & $0.54^{\mathrm{d}}$ & $0.54^{\mathrm{d}}$ & $0.48^{\mathrm{d}}$ & $0.55^{\mathrm{d}}$ & $0.50^{\mathrm{d}}$ \\
\hline Chill shock & $0.55^{\mathrm{d}}$ & $0.52^{\mathrm{d}}$ & $0.53^{\mathrm{d}}$ & $0.50^{\mathrm{d}}$ & $0.48^{\mathrm{d}}$ & $0.53^{\mathrm{d}}$ & $0.50^{\mathrm{d}}$ \\
\hline Warm shock & $0.52^{\mathrm{d}}$ & $0.55^{\mathrm{d}}$ & $0.51^{\mathrm{d}}$ & $0.53^{\mathrm{d}}$ & $0.52^{\mathrm{d}}$ & $0.51^{\mathrm{d}}$ & $0.48^{\mathrm{d}}$ \\
\hline
\end{tabular}

Mann Lake high-fructose corn syrup (HFCS) and sucrose syrup (SS) were chosen for this experiment based on consumer preference among beekeepers we surveyed. Growth medium: bee larva-infused non-nutritive agar. Different superscript letters going down a column of data denote a significant difference. See Figure 1 for water-treated control data and the "Results" section 3.3 for statistical comparison to these treatment values

\subsection{Miticide effects}

A. apis failed to grow, $K_{\mathrm{r}}=0.00 \mathrm{~mm} / \mathrm{h}$, when treated with $0.1 \%$ formic acid, $1.0 \%$ formic acid, and $25 \%$ formic acid (Table IV), which was different from water-treated controls where growth is observed $(P<0.05$; Figure 1$)$. Increasing temperature failed to produce growth (Table IV) unlike water-treated controls $(P<$ 0.05 ; Figure 1). Results with lowest concentration, $0.01 \%$, of formic acid were similar to water-treated controls $(P>0.05$ at each temperature setting), indicating that formic acid has no effect on $A$. apis growth at this low concentration. Growth rate of $A$. apis was 2-3× lower for the highest concentration (3.5\%, of oxalic acid) tested compared to water-treated controls $(P<$ 0.05 at each temperature setting; Table IV, Figure 1). Growth rates for water-treated controls were not significantly different from the growth rates of $A$. apis for $0.01 \%, 0.1 \%$, and
$1.0 \%$ oxalic acid at any of the temperature settings $(P>0.05$; Table IV, Figure 1). Prior exposure to chill or warm temperature did not modify the rate of growth for any of the oxalic acid treatments compared to temperatures where these chill and warm shock cues were not applied ( $P>0.05$; Table IV). Growth of $A$. apis treated with oxalic acid (Table IV) was faster at $35{ }^{\circ} \mathrm{C}$ compared to $32{ }^{\circ} \mathrm{C}(P<0.05)$, which was faster than at $30^{\circ} \mathrm{C}(P<0.05)$, which was faster than at $25{ }^{\circ} \mathrm{C}(P<0.05)$; these growth rates were similar to those of water-treated controls $(P>$ 0.05 at each temperature setting; Figure 1).

\section{DISCUSSION}

Evidence indicates that growth of A. apis increases with increasing temperature at bee colony temperatures from $25{ }^{\circ} \mathrm{C}$ to $35{ }^{\circ} \mathrm{C}$, without experiencing an abrupt, accelerated growth spurt as the result of experiencing a 
Table IV. Formic acid and oxalic acid miticides (* denotes suggested field application concentration) as a supplement in relation to lowering the growth of Ascosphaera apis on bee larva supplemented agar, implementing a $24 \mathrm{~h}$ chill $\left(18{ }^{\circ} \mathrm{C}\right)$ or warm $\left(36^{\circ} \mathrm{C}\right)$ pre-exposure shock

Mean radial growth rate, $\mathrm{mm} / \mathrm{h}\left(K_{\mathrm{r}} \pm \mathrm{SE} \leq 0.006\right)$

\begin{tabular}{|c|c|c|c|c|c|c|c|c|}
\hline \multirow[b]{2}{*}{ Temperature } & \multicolumn{4}{|c|}{$\%$ Formic acid } & \multicolumn{4}{|c|}{$\%$ Oxalic acid } \\
\hline & 0.01 & 0.1 & 1.0 & $25.0 *$ & 0.01 & 0.1 & 1.0 & $3.5^{*}$ \\
\hline $25^{\circ} \mathrm{C}$ & $0.20^{\mathrm{a}}$ & NG & NG & NG & $0.17^{\mathrm{a}}$ & $0.23^{\mathrm{a}}$ & $0.20^{\mathrm{a}}$ & $0.05^{\mathrm{a}}$ \\
\hline Chill shock & $0.22^{\mathrm{a}}$ & NG & NG & NG & $0.22^{\mathrm{a}}$ & $0.18^{\mathrm{a}}$ & $0.22^{\mathrm{a}}$ & $0.07^{\mathrm{a}}$ \\
\hline Warm shock & $0.19^{\mathrm{a}}$ & NG & NG & NG & $0.23^{\mathrm{a}}$ & $0.24^{\mathrm{a}}$ & $0.24^{\mathrm{a}}$ & $0.04^{\mathrm{a}}$ \\
\hline $30{ }^{\circ} \mathrm{C}$ & $0.32^{\mathrm{b}}$ & NG & NG & NG & $0.31^{\mathrm{b}}$ & $0.28^{\mathrm{b}}$ & $0.31^{\mathrm{b}}$ & $0.11^{\mathrm{b}}$ \\
\hline Chill shock & $0.34^{\mathrm{b}}$ & NG & NG & NG & $0.33^{\mathrm{b}}$ & $0.34^{\mathrm{b}}$ & $0.28^{\mathrm{b}}$ & $0.09^{\mathrm{b}}$ \\
\hline Warm shock & $0.32^{\mathrm{b}}$ & NG & NG & NG & $0.30^{\mathrm{b}}$ & $0.31^{\mathrm{b}}$ & $0.29^{\mathrm{b}}$ & $0.11^{\mathrm{b}}$ \\
\hline $32^{\circ} \mathrm{C}$ & $0.41^{\mathrm{c}}$ & NG & NG & NG & $0.44^{\mathrm{c}}$ & $0.41^{\mathrm{c}}$ & $0.39^{\mathrm{c}}$ & $0.14^{\mathrm{c}}$ \\
\hline Chill shock & $0.39^{\mathrm{c}}$ & NG & NG & NG & $0.39^{\mathrm{c}}$ & $0.45^{\mathrm{c}}$ & $0.43^{\mathrm{c}}$ & $0.16^{\mathrm{c}}$ \\
\hline Warm shock & $0.43^{\mathrm{c}}$ & NG & NG & NG & $0.42^{\mathrm{c}}$ & $0.42^{\mathrm{c}}$ & $0.44^{\mathrm{c}}$ & $0.16^{\mathrm{c}}$ \\
\hline $35^{\circ} \mathrm{C}$ & $0.52^{\mathrm{d}}$ & NG & NG & NG & $0.57^{\mathrm{d}}$ & $0.53^{\mathrm{d}}$ & $0.52^{\mathrm{d}}$ & $0.21^{\mathrm{d}}$ \\
\hline Chill shock & $0.55^{\mathrm{d}}$ & NG & NG & NG & $0.56^{\mathrm{d}}$ & $0.54^{\mathrm{d}}$ & $0.56^{\mathrm{d}}$ & $0.23^{\mathrm{d}}$ \\
\hline Warm shock & $0.54^{\mathrm{d}}$ & NG & NG & NG & $0.54^{\mathrm{d}}$ & $0.51^{\mathrm{d}}$ & $0.49^{\mathrm{d}}$ & $0.20^{\mathrm{d}}$ \\
\hline
\end{tabular}

The same superscript letter going down a column of data indicates that the values are not significantly different. $K_{\mathrm{r}}=0.00 \mathrm{~mm} /$ h. Statistical comparisons of these treatment values to data for water-treated controls (Figure 1) are in the "Results" section 3.4

$N G$ no growth

chill or warm shock cue. Instead, growth rate was increased in a smooth rate as the temperature rises. High-fructose corn syrup and sucrose syrup, undiluted and 50:50 mix, did not impact the growth of $A$. apis greatly, except for HFCS Cornsweet-42 and, even with this brand, a response decrease was modest. The sugars fructose and sucrose in their pure form can slow growth of certain fungi on occasion, because these sugars are less exploited as bee food compared to glucose (Jennings and Lysek 1999). Apparently, the individual, percentage composition of fructose, glucose, and other ingredients in the commercially available syrups that are fed to bee colonies are not sufficient to suppress or enhance $A$. apis growth. The $0.1 \%$ fumagillin, $1.0 \%$ oxytetracycline, and $1.0 \%$ tylosin had no effect on growth rate of $A$. apis, and there was no dose response, with or without application in sugar syrups. Fumagillin has bactericidal and fungicidal activities (Agner et al. 2003), but the $0.1 \%$ fumagillin antibiotic applied to bee colonies (and even at the highest $1.0 \%$ fumagillin tested) was not sufficiently high to hinder A. apis growth in our study. When miticides were applied to bee colonies, $25 \%$ formic acid prevented the growth of $A$. apis and $3.5 \%$ oxalic acid was highly suppressive. Organic acids commonly act to suppress fungal growth (Jennings and Lysek 1999), so these negative effects on $A$. apis by formic and oxalic acids are not surprising, especially because the concentrations that are used in bee colonies are rather high in order to exert mite control. We conclude that $A$. apis is tolerant to the treatments that are applied to bee colonies, except for the formic acid and oxalic acid miticides.

We have several observations implying that temperature-growth relations of $A$. apis are not linked to chalkbrood disease (modified from this study; Flores et al. 1996; Aronstein and 
Cabanillas 2012): (1) at $35{ }^{\circ} \mathrm{C}$ where incidence of chalkbrood is observed the least (dropping off to almost no growth), A. apis grows the fastest and has optimal germination, and, conversely, most chalkbrood mummies are observed at $25{ }^{\circ} \mathrm{C}$ in the colony, whereas A. apis grows slowly; (2) attempts failed to enhance growth of $A$. apis by implementing a chilling $\left(18^{\circ} \mathrm{C}\right)$ or warming $\left(36^{\circ} \mathrm{C}\right)$ stress to the fungus, cues known to cause a high incidence of chalkbrood-infected brood, i.e., chalkbrood cannot be attributed to triggering the fungus; (3) colonies treated with sugar syrups and antibiotics that exhibit a high incidence of chalkbrood are treatments that do not promote $A$. apis growth; and (4) colonies treated with formic acid that kills $A$. apis, or oxalic acid that hinders growth of $A$. apis severely, show high incidence of chalkbrood infection, not less. Thus, radial growth rate of A. apis is independent of the cues and treatments that incite chalkbrood or under circumstances where chalkbrood-infected larvae have been observed in the field. This implies that establishment of chalkbrood is bee related, not related to temperature-alterations, or treatment-alteration of the fungus.

The most likely scenario is that poor bee health (compromised immune system) makes the bee larva more prone to A. apis penetration, exploitation, and establishment. Sugar syrups, miticides, and antibiotics are not the cause of chalkbrood, but rather they are signals that are related to other problems associated with declining or poor bee health. Sugar syrup feeding has the effect of causing malnutrition and compromising the bee's immune system (Mao et al. 2013). In addition, excess moisture from feed is especially an issue for beekeepers and chalkbrood (D. Stiglitz, Golden Rule Honey, Leominster, Massachusetts; personal communication 2013). Overuse of broad-spectrum antibiotics has the effect of declining natural resistance mechanisms in the bees by attacking naturally occurring probiotic bacteria (Mudroňová et al. 2011) and likely other bacteria that play a positive defensive role for the bee. Miticides, such as formic acid and oxalic acid suppress growth of beneficial bee colony-associated fungi (Yoder et al. 2008) that provides natural resistance against fungal infections (Gilliam et al. 1988), and use of these miticides necessarily implies that mites are present, presumably resulting in severe colony distress from a high mite load in the bee colony (Sammataro 2012). Bee virus also contributes to declining bee health (de Miranda et al. 2012). Taken together, these factors contribute toward making the bee more prone to attack by opportunistic pathogens, such as A. apis. Owing to these considerations, we conclude that chalkbrood is a signal that something else is wrong with the bee colony that is imposing some sort of stress on the bees that make them less resistant to fight off infection.

\section{ACKNOWLEDGMENTS}

We thank Diana Sammataro (Carl Hayden Honey Bee Research Center, Tucson, Arizona) for her helpful comments on an earlier draft of this article. Support for this project was made possible by a Wittenberg University Research Grant to AJJ and CLM from funding provided by James R. Wymer.

Evaluation in vitro de solutions sucrées, d'antibiotiques et d'acaricides sur le développement du pathogène d'abeilles, Ascosphaera apis: l'important est de maintenir les abeilles en bonne santé pour prévenir la maladie du couvain plâtré

Colonie d'abeilles / mycose / acide formique / acide oxalique / sirop de maïs à haute teneur en fructose

In vitro Analyse von Zuckersyrup, Antibiotika und Akariziden auf das Wachstum des Honigbienenpathogens Ascophaera apis: Kalkbrutvorbeugung bedeutet, die Bienen gesund zu halten

Bienenvolk / Pilzinfektion / Ameisensäure / Oxalsäure / Fruktose-Maissyrup / Antibiotika

\section{REFERENCES}

Agner, G., Gyórbiró, A., Valkó, I., Vasvári-Debreczy, L., Szabó, A., Farkas, G., Halász, J., Podányi, B., Brlik, J., Simon, K., Hermecz, I. (2003) Light- and temperature-induced degradation of fumagillin. Acta Pharm. Hung. 73, 41-45 
Aliano, N.P., Ellis, M.D., Siegfried, B.D. (2006) Acute contact toxicity of oxalic acid to Varroa destructor (Acari: Varroidae) and their Apis mellifera (Hymenoptera: Apidae) hosts in laboratory bioassays. J. Econ. Entomol. 99, 1579-1582

Amrine Jr., J.W., Noel, R.C., Webb, D. (2007) Results of $50 \%$ formic acid fumigation of honey bee hives [Apis mellifera ligustica (Hymenoptera: Apidae)] to control varroa mites (Acari: Varroidae) in brood combs in Florida, U.S.A. Int. J. Acarol. 33, 99-109

Aronstein, K.A., Cabanillas, H.E. (2012) Chalkbrood reexamined. In: Sammataro, D., Yoder, J.A. (eds.) Honey Bee Colony Health: Challenges and Sustainable Solutions, pp. 121-130. CRC Press, Boca Raton

Baldrian, P., Gabriel, J. (2002) Intraspecific variability in growth response to cadmium of the wood-rotting fungus Piptoporus betulinus. Mycologia 94, 428436

Chiesa, F., Milani, N., D’Agaro, M. (1989) Observations of the reproductive behavior of Varroa jacobsoni Oud.: techniques and preliminary results. In: Cavalloro, R. (ed.) Proceeding of the Meeting of the EC-Experts' Group, Udine 1988, pp. 213-222. CEC, Luxembourg

Christensen, M., Gilliam, M. (1983) Notes on the Ascosphaera species inciting chalkbrood in honey bees. Apidologie 14, 291-297

Cooper, B. (1980) Fluctuating broodnest temperature rhythm. British Isles Bee Breeders News 18, 12-16

de Miranda, J.R., Gauthier, L., Ribière, M., Chen, Y.P. (2012) Honey bee viruses and their effect on bee and colony health. In: Sammataro, D., Yoder, J.A. (eds.) Honey Bee Colony Health: Challenges and Sustainable Solutions, pp. 71-102. CRC Press, Boca Raton

Flores, J.M., Ruiz, J.A., Ruz, J.M., Puert, F., Bustos, M., Padilla, F., Campano, F. (1996) Effect of temperature and humidity of sealed brood on chalkbrood development under controlled conditions. Apidologie 27, 185-192

Gilliam, M. (1986) Infectivity and survival of the chalkbrood pathogen. Ascosphaera apis, in colonies of honey bees, Apis mellifera, Apidologie 17, 93100

Gilliam, M., Taber III, S., Lorenz, B.J., Prest, D.B. (1988) Factors affecting development of chalkbrood disease in colonies of honey bees, Apis mellifera, fed pollen contaminated with Ascosphaera apis. J. Invertebr. Pathol. 52, 314-325

Hitchcock, J.D., Moffett, J.O., Lackett, J.J., Elliot, J.R. (1970) Tylosin for control of American foulbrood disease in honey bees. J. Econ. Entomol. 63, 204207

Huang, W.-F., Solter, L.F., Yau, P.M., Imai, B.S. (2013) Nosema ceranae escapes fumagillin control in honey bees. Plos Pathogens 9(3), e1003185. doi:10.1371/journal.ppat.1003185
Jennings, D.H., Lysek, G. (1999) Fungal Biology: Understanding the Fungal Lifestyle. Springer, New York

Jimenez, M.I., Aguar, M.P., Olmo, V., Galiano, A., Martinez Fernandez, A.R. (1994) In vitro antifungal activity of IQB-863-F, amphotericin B and other imidazole derivatives in front of Ascosphaera apis. Rev. lberoam. Micol. 11, 7-9

Johnson, R.N., Zaman, M.T., Decelle, M.M., Siefel, A.J., Tarpy, D.R., Siegel, E.C., Starks, P.T. (2005) Multiple micro-organisms in chalkbrood mummies: evidence and implications. J. Apic. Res. 44, 29-32

Katznelson, H., Jamieson, C.A. (1952) Control of Nosema disease of honeybees with fumagillin. Science 115, 70-71

Mao, W., Schuler, M.A., Berenbaum, M.R. (2013) Honey constituents up-regulate detoxification and immunity genes in the western honey bee Apis mellifera. Proc. Nat. Acad. Sci. 110, 8842-8846

Mudroňová, D., Toporčák, J., Nemcová, R., Gancarčíková, S., Hajdučková, V., Rumanovská, K. (2011) Lactobacillus sp. as a potential probiotic for the prevention of Paenibacillus larvae infection in honey bees. J. Apic. Res. 50, 323-324

Peng, C.Y.-S., Mussen, E., Fong, A., Cheng, P., Wong, G., Montague, M.A. (1996) Laboratory and field studies on the effects of the antibiotic tylosin on honey bee Apis mellifera L. (Hymenoptera: Apidae) development and prevention of America foulbrood disease. J. Invertebr. Pathol. 67, 65-71

Rademacher, E., Harz, M. (2006) Oxalic acid for the control of varroosis in honey bee colonies - review. Apidologie 37, 98-120

Sahinler, N., Kurt, S. (2004) A study on antifungal activity of formic acid and propolis extract against chalkbrood disease pathogen Ascosphaera apis. J. Anim. Vet. Adv. 3, 554-556

Sammataro, D. (2012) Global status of honey bee mites. In: Sammataro, D., Yoder, J.A. (eds.) Honey Bee Colony Health: Challenges and Sustainable Solutions, pp. 37-54. CRC Press, Boca Raton

Sokal, R.R., Rohlf, F.J. (1995) Biometry: The Principles and Practice of Statistics in Biological Research. Freeman, San Francisco

Southwick, E.E., Heldmaier, G. (1987) Temperature control in honey bee colonies. BioScience 37, 395399

Underwood, R.M., Currie, R.W. (2005) Effect of concentration and exposure time on treatment efficacy against varroa mites (Acari: Varroidae) during indoor winter fumigation on honey bees (Hymenoptera: Apidae) with formic acid. J. Econ. Entomol. 98, 1802-1809

Winston, P.W., Bates, D.S. (1960) Saturated solutions for the control of humidity in biological research. Ecology 41, 232-237 
Yamaji, K., Ishimoto, H., Usui, N., Mori, S. (2005) Organic acid and water-soluble phenolics produced by Paxillus sp. 60/92 together show antifungal activity against Pythium vexans under acidic culture conditions. Mycorrhiza 15, 17-23
Yoder, J.A., Christensen, B.S., Croxall, T.J., Tank, J.L., Sammataro, D. (2008) Suppression of growth rate of colony-associated fungi by high fructose corn syrup feeding supplement, formic acid, and oxalic acid. J. Apic. Res. 47, 126-130 